\title{
PENGARUH MEDIA SOSIAL TERHADAP PROSES PEMILIHAN HOTEL BAGI WISATAWAN (STUDI KASUS PADA MAHASISWA PROGRAM STUDI PENGELOLAAN PERHOTELAN UNIVERSITAS PELITA HARAPAN)
}

\section{THE INFLUENCE OF SOCIAL MEDIA ON THE HOTEL SELECTION PROCESS FOR TOURISTS (CASE STUDY IN HOTEL MANAGEMENT STUDY PROGRAM PELITA HARAPAN UNIVERSITY)}

\author{
Rosianna Sianipar ${ }^{1)}$ \\ 1) Program Studi Pengelolaan Perhotelan - Universitas Pelita Harapan \\ Diterima Tanggal 10 Oktober 2020 Disetujui 01 Desember 2020
}

\begin{abstract}
The Purpose of this research is to identify how social media can influence the decision taken by tourist to choose a hotel and to acknowledge what steps must the tourist undergo in choosing the hotel throughout social media. The research is using qualitative research approach. By doing qualitative research the researcher can collect data in the form of explanations and opinions given by respondents. The interview technique used in this research is structured and unsructured interview. The researcher complied the information list needed and asked the questions directly to the respondents. This research is using non probability samples, that is judgment samplings. In using Judgement samplings, more effort is needed to find and get access to the person who has the information needed. The respondents in this research were the students of Hotel Management Faculty of Universitas Pelita Harapan.
\end{abstract}

Keyword: Technology, Hotels, Students

\begin{abstract}
Abstrak
Penelitian ini bertujuan untuk mengidentifikasi bagaimana media sosial dapat mempengaruhi pengambilan keputusan wisatawan dalam menentukan pemilihan hotel dan untuk mengetahui apa saja tahapan yang dilalui oleh wisatawan dalam menentukan pemilihan hotel melalui media sosial. Penelitian ini menggunakan metode kualitatif. Dengan melakukan penelitian kualitatif, peneliti dapat mengumpulkan data-data yang berupa penjelasan dan opini yang diberikan oleh responden. Teknik wawancara yang digunakan di dalam penelitian ini adalah menggunakan teknik wawancara terstruktur dan tidak terstruktur. Peneliti Menyusun terlebih dahulu daftar informasi yang diperlukan. Kemudian peneliti akan mengajukan pertanyaan secara langsung kepada responden saat wawancara berdasarkan daftar informasi tersebut dan jawaban yang diberikan responden. Dalam penelitian ini menggunakan sampel non probabilitas, yaitu judgement sampling. Judgement sampling menggunakan usaha lebih untuk menemukan dan mendapatkan akses kepada orang yang memiliki informasi yang dibutuhkan. Yang menjadi responden dalam penelitian ini adalah mahasiswa Program Studi Pengelolaan Perhotelan, Universitas Pelita Harapan.
\end{abstract}

Kata Kunci $\quad$ : Teknologi, Hotel, Mahasiswa

Pendahuluan

\subsection{Latar Belakang Masalah}

Perkembangan teknologi, informasi dan komunikasi yang terus meningkat membuat jumlah pengguna internet juga semakin tinggi diseluruh dunia setiap tahunnya tak terkecuali Indonesia. Pusat Kajian Komunikasi UI melakukan rilis pers tentang hasil survei profil pengguna internet di Indonesia.Hasil survei ini merupakan hasil kerjasama dengan APJII yang merupakan sumber informasi tentang data pengguna internet di Indonesia saat ini.Survei tersebut menyebutkan bahwa jumlah pengguna internet di Indonesia telah mencapai 88,1 juta pengguna. Jumlah pengguna yang tinggi 
menjadikan Indonesia sebagai pasar yang potensial untuk Kegiatan bisnis secara online.

Berbagai hal yang sudah dilakukan untuk mempromosikan pariwisata antara lain dengan menggunakan media televise, radio, iklan, brosur, pameran dan yang terbaru adalah dengan menggunakan media sosial.

Berbeda dengan media konvensional yang sudah bertahun -tahun lalu sering digunakan untuk promosi pariwisata, promosi dengan menggunakan media sosial masih tergolong baru dan tampaknya mulai mempunyai daya tarik tersendiri bagi pelaku-pelaku Industri pariwisata untuk promosi melalui media sosial. Hal tersebut dapat dilihat dengan munculnya daerah pariwisata yang mulai memiliki akun akun media sosial untuk pariwisatanya masing - masing.

Hal tersebut tampaknya sejalan dengan potensi yang dimiliki media sosial dalam mempromosikan pariwisata. Tercatat sebanyak 129,2 juta pengguna media sosial di Indonesia (APJII, 2016), dengan pengguna melebihi setenganh jumlah penduduk Indonesia itu potensi media sosial sebagai media promosi pariwisata sangat besar.

Media sosial adalah perkembangan mutakhir dari teknologi-teknologi web baru berbasis internet yang memudahkan semua orang untuk berkomunikasi, berpartisipasi saling berbagi, dan membentuk suatu jaringan online, sehingga dapat menyebarluaskan konten mereka sendiri (Zarella, 2010)

Media sosial yang bisa disebut juga jejaring sosial adalah suatu layanan berbasis Web yang memungkinkan setiap individu untuk membangun hubungan sosial melalui dunia maya seperti membangun profil tentang dirinya sendiri, menunjukkan koneksi seseorang dan memperlihatkan hubungan apa saja yang ada antara satu pemilik dengan pemilik akun lainnya dalam sistem yang disediakan, dimana masing-masing jejaring sosial memiliki ciri khas dan sistem yang berbeda-beda (Boyd dan Ellison,2007).Contohnya seperti Facebook, Instagran, Youtube dan lain - lain.

Facebook adalah situs jejaring sosial yang dapat dijadikan sebagai tempat untuk menjalin hubungan pertemaman dengan semua orang yang ada dibelahan dunia untuk dapat digunakan oleh manusia untuk berkomunikasi satu dengan yang lainnya, Facebook merupakan situs pertemanan yang dapat digunakan oleh manusia untuk bertukar informasi , berbagai foro, video, dan lainnya (Madcoms: 2010). Sedangkan Instagram merupakan salah satu fitur yang dimiliki oleh telepon pintar.Instagram ini sendiri merupakan aplikasi handphone yang berbasis android, selain itu Instagram juga merupakan aplikasi yang digunakan untuk mengambil foto , mengelola foto, mengedit foto, memberi efek filter pada foto dan membagikan foto tersebut kepada semua orang.

Sekarang Instagram tak hanya dapat mem bagikan foto saja, aplikasi ini juga dapat digunakan bagi yang mengunggah video selama 15 detik.Awalnya aplikasi ini lebih dominan digunakan bagi yang mempunyai kesenangan dalam mengambil foto dari telepon pintarnya kemudian membagikan hasil jepretannya ke Instagram.Foto - foto yang di unggah ini bias saja berupa foto pemandangan, foto keluarga sanak saudara, foto koleksi buku, dan sebagainya (Agustina, 2016).

Di Indonesia kurang lebih 45 juta penduduk

menggunakan Instagram secara aktif. Dari data tersebut Indonesia merupakan komunitas Instagram terbesar di Asia Pasifik, serta menjadi salah satu pasar terbesar di dunia (WWW.bisnis.tempo.co., 26 Juli 2017). Selain facebook, perkembangan pengguna instagram sangat besar. Jika menelusuri para pencarian di Instagram dengan mengetik nama suatu kota atau daerah, bahkan negara, feeds yang ditampilkan adalah pariwisata-pariwisata tempat tersebut.Akun-akun tersebut dikelola baik secara perorangan, kelompok maupun institusi.Hal demikian membuat para calon wisatawaan dapat memperoleh informasi dengan mudah.

Dalam komunikasi pemasaran sendiri media sosial termasuk dalam Interracctive Marketing, karena media sosial memungkinkan terjadinya arus informasi dengan mudah. Dalam komunikasi pemasaran sendiri media sosial memungkinkan terjadinya arus informasi timbal balik yang memungkinkan pengguna dapat berpartisipasi dan memodifiasi bentuk da nisi informasi pada saat itu juga ( real time ).

Sedangkan partisipasi adalah berasal dari Bahasa Inggiris participate yang artinya mengikutsertakan, ikut mengambil bagian (Willie Wijaya:2004). Fasli Djalal dan Dedi

Supriadi (2001) juga mengemukakan partisipasi dapat juga berarti bahwa pembuat keputusan menyarankan kelompok atau 
masyarakat ikut terlibat dalam bentuk penyampaian saran dan pendapat, barang, keterampilan, bahan dan jasa. Partisipasi juga berarti kelompok mengenal masalah mereka sendiri, mengkaji pilihan mereka, membuat keputusan, dan memecahkan masalahnya. Pertumbuhan sektor pariwisata di Indonesia di tahun 2018 mengalami pertumbuhan yang sangat pesat yaitu 12,58 persen. Sehingga dapat dijadikan fokus dalam lokomotif pertumbuhan ekonomi di Indonesia. Salah satu Langkah pemerintah dalam mempertahankan pertumbuhan pariwisata tersebut adalah dengan membuat program 10 Bali baru, dimana dengana adanya program tersebut, sector pariwisata meraih devisa sebanyak 17,6 miliar dollar AS atau setara dengan 264,4 triliun di penghujung tahun 2019. (Kompas.com,2019)

Dalam perkembangannya pariwisata tidak terlepas dari adanya dukungan teknologi dan informasi. Penggunaan teknologi sangat berperan dalam aktivitas masyarakat saat ini, begitu juga dengan aktivitas berwisata. Teknologi sangat dibutuhkan terutama untuk melakukan aktivitas pemasaran pariwisataa maupun digitalisasi dalam menyalurkan informasi terkait dengan sebuah produk wisata. Menurut pemaparan Deputi Bidang Pengembangan Pemasaran II Kementerian Pariwisata, Rizki Handayani Mustafa, pemerintah daerah sudah banyak yang membuat website untuk menonjolkan destinasi popular di wilayahnya. Namun yang menjadi kekurangannya adalah mereka jarang melakukan pembaruan (update) informasi tersebut sehingga kegiatan promosi destinasi dan event tidak berjalan dengan maksimal.

Di daerah-daerah, kabupaten, kota maupun provinsi ada banyak sekali produk wisata yang bagus namun kurang dalam promosi dan informasinya. Padahal perubahan perilaku wisatawan berubah menjadi search dan share. Bahkan 70 persen dari wisatawan sudah mengakses informasi wisata melalui perangkat digital. Dalam 5 tahun terakhir perilaku konsumen berubah. Mereka ingin melakukan perencanaan dan perjalanan ke suatu destinasi namun dilakukan sendiri. Terutama milenial yang ingin mencari tempat jalan-jalan sendiri, tentunya yang mudah dan gampang diakses.

Minat berkunjung wisatawan dalam Marketing for Hospitality and Tourism di asumsikan sama dengan miant pembelian (Kotler, 2006 :198). Menurut Kotler dan Susanto (2000:165). Minat dapat diartikan sebagai suatu dorongan yang berasal dari rangsagan internal seseorang yang memotivasi tindakan, dimana dorongan tersebut dipengaruhi oleh stimulus dan perasaan positif suatu produk.

Sedangkan minat beli menurut Kinnear dan Taylor (dalam Fitriah, 2018 :77) merupakan bagian dari perilaku konsumen dalam sikap mengkomsumsi, kecenderungan responden dalam bertindak sebelum keputusan pembelian benar benar dilakukan. Menurut Sukmawati dan Suryono (dalam Annafik dan Raharjo, 2021) minat beli adalah tahap dimana seseorang membentuk pilihan mereka diantara beberapa merek dan yang akhirnya akan melakukan pembelian suatu barang ataupun jasa dengan didasari oleh beberapa pertimbangan.Yoestini dan Sheilla (dalam Fitrah, 2018:78) menyatakan minat beli diperoleh dari proses belajar dan suatu pemikiran yang dapat membentuk presepsi.

Saat ini media sosial memang memiliki banyak manfaat bagi masyarakat. Salah satu manfaatnya adalah, membuat setiap orang bisa bersosialisasi dengan banyak orang menggunakan waktu dan sarana yang efektif untuk memberitahukan sebuah informasi.

Dalam UU No.10 tahun 20U09 Tentang Kepariwisataan juga disebutkan bahwa pariwisata didukung oleh fasilitas serta layanan yang disediakan oleh masyarakat, pengusaha, pemerintah dan pemerintah daerah. Salah satu fasilitas yang disediakan oleh masyarakat, pengusaha, pemerintah dan pemerintah daerah adalah hotel.

Sesuai dengan perkembangan media sosial diatas mengenai manfaat media sosial dalam industri pariwisata, maka penulis tertarik untuk membahas mengenai pengaruh media sosial terhadap proses pemilihan hotel. Dalam penelitian ini juga akan dibahas tahapan yang akan dilakukan wisatawan untuk memilih hotel melalui media sosial sehingga akhirnya menetapkan pilihannya. Agar penulisan ini tidak menyimpang maka penulis telah menentukan responden dalam penelitian ini adalah wisawatan Indonesia yang berusia 18-25 tahun, yang masih aktif dalam perkuliahan, 
khususnya mahasiswa di Program Studi Pengelolaan Perhotelan, Universitas Pelita Harapan dan aktif menggunakan media sosial dalam proses pemilihan hotel di Indonesia. Adapun judul dari penelitian ini adalah pengaruh media sosial terhadap proses pemilihan hotel bagi mahasiswa

\subsection{Identifikasi Masalah}

Identifikasi masalah pada penelitian ini adalah : " Bagaimana pengaruh media sosial terhadapa proses pemilihan hotel bagi wisatawan?"

\subsection{Tujuan dan Manfaat Penelitian}

Tujuan dari penelitian ini adalah : Untuk mengetahui pengaruh yang dihadapkan dari media sosial terhadap proses pemilihan hotel bagi wisatawan. Berdasarkan tujuan penelitian , maka ada dua(2) manfaat yang didapatkan dari penelitian ini yaitu :

\section{a. Manfaat Akademis}

Melalui penelitian ini diharapkan dapat menjadi refrensi dan memberikan masukan untuk peneliti selanjutnya mengenai studi tentang pengaruh media sosial lain bagi aspekaspek industry perhotelan lainnya.

\section{b. Manfaat Praktis}

Penelitian ini dapat memberikan pemahaman serta refrensi tentang penggunaan media sosial yang digunakan di dalam industri perhotelan untuk memudahkan wisatawanwisatawan yang ada.

\section{Tinjauan Pustaka}

\subsection{Media Sosial}

Istilah media sosial tersusun dari dua kata, yakni "media " dan " sosial ". " Media " diartikan sebagai alat komunikasi (Laughey, 2007; McQuail, 2003). Sedangkan kata “ sosial “ diartikan sebagai kenyataan sosial bahwa setiap individu melakukan aksi yang memberikan konstribusi kepada masyarakat.Pernyataan ini menegaskan bahwa pada kenyataannya, media dan semua perangkat lunak merupakan :" sosial"atau dalam mak-na bahwa keduanya merupakan produk dari proses sosial (Durkheim dalam Fuchs,2014)
Perdagangan RI(2014:25) menyebutkan bahwa media sosial adalah sebuah media online, dimana para penggunanya (user) melalui aplikasi berbasis internet dapat berbagi, berpartisipasi, dan menciptakan konten berupa blog, wiki, forum, jejaring sosial, dan ruang virtual yang didukung oleh teknologi multimedia yang semakin canggih. "Social media involves the use of web technologies to transform one- way communication into an interactive online dialogue. Akey of component of social media is the creation and exchange of user generated conten. "(Dixon,2012,p.2).

New media merupakan media yang menawarkan digitization, conver- gence, interactivity, dan development of network terkait pembuatan pesan dan penyampaian pesannya. Kemampuannya menawarkan interaktifitas ini memungkinkan pengguna dari new me- dia memiliki pilihan informasi apa dikomsumsi, sekaligus mengendalikan keluaran informasi yang dihasilkan ser- ta melakukan pilihan-pilihan yang diinginkannya.

Kemampuan menawarkan suatu interactivity inilah yang merupakan konsep sentral dari pemahaman tentang new media. (Flew,2002,p.11-22).

Munculnya virtual reality , komunitas virtual identitas virtual merupakan fenomena yang banyak muncul seiring dengan hadirnya new media.Fenomena ini muncul karena new media memungkinkan penggunanya untuk menggunakan ruang seluas-luasnya di new media, memperluas jaringan seluas-luasnya, dan menunjukkan identitas yang lain dengan yang memiliki pengguna tersebut didunia nyata. (Flew, 2002,p.25).

Menurut Philip Kotler dan Kevin Keller, media sosial merupakan sarana bagi konsumen untuk berbagi informasi teks, gambar, audio, dan video degan satu sama lain dan dengan perusahaan atau sebaliknya.

Media sosial saat ini sangat berperan penting medongkrak kemajuan bisnis. (dalam Walid, 2018,p.2) Media sosial telah mengubah cara masyarakat berkomunikasi dan mencari informasi. Media sosial juga mengubah cara konsumen berkomunikasi dan berbagi informasi tentang merek sehingga konsumen mampu berdiskusi, beropini, dan membagi penglaman mereka dengan merek tertentu (Nielsen, 2011,p.2). 


\section{Kotler}

dan

Keller

(2013,p.478).menjelaskan bahwa Interactive Marketing (Pemasaran Interaktif) adalah kegiatan dan program online yang dirangcang untuk melibatkan pelanggan atau prospek dan secara langsung atau tidak langsung meningkatkan kesadaran, memperbaiki citra, atau menciptakan penjualan produk dan jasa,

\subsection{Pariwisata}

Suwantoro (2004, p.3) mendefinisikan istlah pariwisata, yaitu suatu perubahan tempat tinggal semnetara seseorang diluar tempat tinggalnya karena suatu alasan dan bukan untuk melakukan kegiatan yang menghasilkan upah.

Dengan demikian dapat dikatakan bahwa perjalanan yang dilakukan oleh seseorang atau lebih dengan tujuan antara lain untuk mendapatkan kenikmatan dan memenuhi hasrat ingin mengetahui sesuatu.Dapat juga karena kepentingan yang berhubungan dengan kegiatan olah raga untuk kesehatan, konvensi, keagamaan, dan keperluan usaha lainnya.Potensi wisata adalah semua obyek ( alam, budaya, buatan) yang memerlukan banyak penanganan agar dapat memberikan nilai daya Tarik bagi wisatawan (Janianto Damanik dan Helmut F. Weber, 2006,p.11).

Istilah Pariwisata berhubungan erat dengan pengertian perjalanan wisata, yaitu sebagai suatu perubahan tempat tinggal sementara seseorang diluar tempat tinggalnya karena suatu alasan dan bukan merupakan kegiatan yang menghasilkan upah.Dengan demikian dapat dikatakan parawisata merupakan suatu perjalanan yang dilakukan oleh seseorang atau lebih dengan tujuan anatara lain untuk mendapatkan kenikmatan dan memenuhi hasrat ingin mengetahui sesuatu. Dapat juga karena kepentingan yangberhubungan dengan kegiatan olah raga untuk kesehatan, konvensi , keagamaan, dan keperluan uasaha lainnya (Gamal,2004:3).

Kepariwisataan didefinisikan sebagai keseluruhan kegiatan yang terkait dengan pariwisata dan bersifat multidimensi serta multidisiplin yang muncul sebagai wujud kebutuhan setiap orang dan negara serta interaksi antara wisatawan dan masyarakat setempat, sesame wisatawan, pemerintah, pemerintah daerah, dan pengusaha (UU No.10 Tahun 2009 tentang Kepariwisataan (revisi dari UU No.9 Tahun 1990 Kepariwisatataan).
Kegiatan pariwisataaa merupakan salah satu bentuk aktivitas manusia, seperti dijelaskan oleh Michael Chubb, et. Al., (1981 dalam Sari, 2004) yang mengklasifikasikan aktivitas manusia menjadi lima hal yaitu rekreasi, kebutuhan phsik, spiritual, pekerjaan dan pendidikan, serta tugas-tugas keluarga dan kemasyarakatan.Pnedapat lain menyebutkan bahwa pariwisata adalah keseluruhan hubungan antara manusia yang hanya berada untuk sementara waktu dalam suatu tempat kediaman dan berhubungan dengan manusia-manusia yang tinggal di tempat itu (Gluckman,1997 dalam Warpani, 2006)

\subsection{Wisatawan}

Seseorang atau sekelompok orang melakukan suatu perjalanan wisata disebut dengan wisatawan (tourist) jika lama tinggalnya sekurang-kurangnya 24 jam didaerah atau dinegara yang dikunjungi.Apabila mereka tinggal di daerah atau negara yang dikunjungi dengan waktu kurang dari 24 jam maka mereka disebut pelancong (excursionist). UIOTO (the international Union of Travel Organization) menggunakan batassan mengenai wisatawan umum. Pengunjung (visitor), yaitu setiap orang yang datang kesuatu negara atau tempat tinggal lain biasanya dengan maksud apapun terkecuali untuk melakukan pekerjaan yang menerima upah.Ada dua kategori mengenai sebutan pengunjung, yakni : Wisatawan adalah seseorang yang melakukan perjalanan paling tidak sejauh $80 \mathrm{~km}$ (50mil) dari rumahnya dengan tujuan rekreasi.Menurut Nyoman (2003:14), wisatawan adalah " orang yang melakukan kegiatan wisata atau orang yang melakukan perjalanan untuk sementara waktu ke tempat atau daerah yang sama sekali masih asing baginya "

Menurut Yoeti jenis dan macam wisatawan, yaitu:

- Wisatawan asing

- Domestic foreign tourist

- Destic Tourist

- Indigeneous Tourist

- Transit Tourist

- Business Tourist

Dari penjelasan tersebut, dapat dikatakan bahwa asal wisatawan yang melakukan wisata di Indonesia terdapat dua kelompok, yaitu 
wisatawan domestic (warga negara Indonesia) dan wisatawan asing (warga negara asing)

Definisi wisatawan Soekadijo(2000), wisatawan adalah pengunjung di negara yang dikunjungin setidak-tidaknya tinggal 24 jam dan yang datang berdasarkan motivasi :

1. Mengisi waktu senggang atau bersenang -senang, berlibur, untuk alasan kesehatan, studi, keluarga dan sebagainya

2. Melakukan perjalan untuk keperluan bisnis

3. Melakukan perjalanan untuk mengunjungi pertemuan-pertemuan atau sebagai utusan (ilmiah, diplomatic, keagamaan, olahraga dan sebagainya)

4. Dalam Rangka pelayaran pesiar, jika kalau ia tinggal kurang dari 24 jam

\section{Metode Penelitian}

Penelitian ini menggunakan metode kualitatif. Dengan melakukan penelitian kualitatif, peneliti dapat mengumpulkan datadata yang berupa penjelasan dan opini yang diberikan oleh responden. Data-data yang terkumpulkan tidak digunakan untuk menguji, maka peneliti memutuskan untuk melakukan penelitian ini dengan menggunakan metode kualitatif.

Johnson dan Christensen (2017:34) menjelaskan bahwa data yang akan dikumpulkan pada metode penelitian kualitatif akan berupa wawancara secara mendalam, observasi terhadap responden, catatan dan

\section{Hasil dan Pembahasan}

Berdasarkan kuesioner online yang disebar, didapat 100 responden yang valid dalam mengisi kuesioner tersrbut. 100 orang responden tersebut merupakan mahasiswa Program Studi Pengelolaan Perhotelan Universitas Pelita Harapan dengan kisaran usia 19-20 tahun. Terdapat 133 responden yang mengisi kuesioner online tersebut, namun hasil dari pengisian responden tersebut tidak valid.

Dari 100 orang responden, sebanyak $70 \%$ memilih hotel budget ( bintang 1-bintang 3) ketika melakukan perjalanan, dimana para responden ini melakukan perjalanan sebanyak 3 kali dalam setahun untuk berlibur baik Bersama keluarga maupun teman-teman. Berdasarkan hasil dari responden juga dapat dilihat bahwa sebanyak $78 \%$ responden pertanyaan terbuka-tertutup dan merupakan instrumen dalam mengumpulkan data primer. Penelitian ini menggunakan metode penelitian kualitatif fenomenologi. Peneliti menggunakan metode penelitian kualitatif fenomenologi karena data yang akan dikumpulkan merupakan kejadian mengenai perjalanan yang dilakukan oleh masing-masing responden, dan peneliti harus memahami setiap penjelasan yang diberikan responden agar data yang dikumpulkan dapat diolah dengan baik.

Menurut Sekaran dan Bougie (2017:113) wawancara atau interview adalah percakapan antara dua atau lebih orang yang mengandung maksud tertentu. Teknik wawancara yang digunakan di dalam penelitian ini adalah menggunakan teknik wawancara terstruktur dan tidak terstruktur. Peneliti Menyusun terlebih dahulu daftar informasi yang diperlukan. Kemudian peneliti akan mengajukan pertanyaan secara langsung kepada responden saat wawancara berdasarkan daftar informasi tersebut dan jawaban yang diberikan responden. Peneliti melakukan kedua teknik wawancara tersebut dengan tujuan agar data yang didapat tidak meluas tetapi mendalam.

Dalam penelitian ini menggunakan sampel non probabilitas, yaitu judgement sampling. Judgement sampling menggunakan usaha lebih untuk menemukan dan mendapatkan akses kepada orang yang memiliki informasi yang dibutuhkan.

memilih hotel dengan kualitas pelayanan yang baik, sedangkan $22 \%$ lebih memilih harga yang murah dalam memilih hotel untuk ditempati.

Berdasarkan data dari 100 responden, ratarata penggunaan media sosial dalam sehari bisa mencapai 4-5 jam sehari. Media sosial yang paling banyak digunakan adalah Instagram, Youtube, Whatsapp, Line dan Twitter. Dari hasil kuesioner online dapat disimpulkan bahwa media sosial merupakan sebuah tempat atau platform dimana orang-orang dapat melakukan komuniakasi dengan orang-orang baik yag dekat maupun jauh, tempat untuk orang-orang mengekspresikan diri dengan foto dan video, tempat untuk mencari informasi, mencari inspirasi dari foto dan video serta untuk menambah pengetahuan. 
Perkembangan media sosial di kalangan mahasiswa/responden ini juga dapat bermanfaat dalam mencari tahu ulasan tentang sebuah akomodasi, baik dalam mencari ulasan tentang harga maupun kualitas sebuah akomodasi. Media sosial saat ini banyak digunakan oleh perusahaan akomodasi dalam mempromosikan akomodasi tersebut. Tidak hanya sebagai sarana promosi, media sosial juga dapat digunakan untuk menjaga hubungan/relasi dengan pihak luar.

Instagram merupakan media sosial yang paling banyak digunkan oleh responden karena banyak menyajikan ulasan dan promosi dalam bentuk video dan foto yang menarik disertai dengan caption yang menarik juga. Yang kedua adalah penggunaan Youtube yang banyak menyajikan ulasan tentang berbagai hal dalam bentuk video yang telah dikemas dengan semenarik mungkin bahkan banyak dipromosikan oleh tokoh berpengaruh (influencer). Yang ketiga adalah Whatsapp yang sudah umum digunakan untuk berkomunikasi dan berbagi informasi dengan sesame. Yang keempat adalah Line, penggunaannya hampir sama dengan Whatsaap namun dikemas lebih menarik dengan berbagai fitur menarik yang disesuaikan dengan kebutuhan anak-anak milenials saat ini. Dan yang kelima adalah Twitter, platform yang akhir-akhir ini Kembali melejjit dikalangan milenials ini juga merupakan sarana yang banyak digunakan untuk membagikan hasil dari apa yang kita pikirkan bahkan untuk mendapat informasi tertentu. Twitter juga masih banyak digunakan sebagai sarana promosi oleh perusahaan akomodasi saat ini.

Berdasarkan data dari 100 responden, sebanyak $75 \%$ memilih platform Traveloka sebagai sarana dalam membeli akomodasi melalui online. Hal tersebut dikarenakan kemudahan dalam mengakses platform tersebut dan banyaknya promo yang diberikan platform tersebut. Sedangkan $23 \%$ memilih Tiket.com dan sisanya $2 \%$ memilih platform online lainnya seperti Pegi-Pegi. Dari 100 responden, $80 \%$ responden menghabiskan 1 juta rupiah per malam untuk harga akomodasi yang mereka pilih.

Berdasarkan data dari responden, dengan mengunggah sebuah informasi/promosi lewat media sosial merupakan hal yang efektif dalam mendapat target pasar dengan profil responden tersebut. Selain itu dengan mengunggah foto yang menarik (instagramable) dapat menggugah konsumen untuk memilih akomodasi tersebut. Jika foto, video maupun informasi yang di tampilkan menarik dan kekinian, maka hal tersebut akan membuat mereka memilih akomodasi tersebut.

Ulasan yang buruk dari tamu dapat menjadi faktor tertinggi dalam memilih sebuah akomodasi. Responden akan langsung memutuskan untuk tidak menggunakan akomodasi tersebut dalam perjalanan yang dilakukan. Itulah sebaiknya dalam era digital ini, diperlukan membangun imej yang positif melalui media sosial yang dimiliki oleh perusahaan akomodasi, apalagi ketika yang menjadi target pasar adalah milenial.

Adapun sisi negatif dari media sosial adalah para pengguna saat ini sangat mudah untuk percaya terhadap berita hoax. Para pengguna juga menjadi ketagihan dalam menggunakan media sosial sehingga membuat aktivitas sehari-hari menjadi tidak produktif.

Berdasarkan data dari responden, tahapan dalam memilih hotel/akomodasi melalui media sosial berawal dari keinginan atau kebutuhan untuk berlibur sehingga membuat responden ingin melakukan pencarian mengenai tujuan dari perjalanan yang akan mereka lakukan. Keinginan untuk melakukan perjalanan juga dapat timbul ketika melihat unggahan yang menarik di media sosial. Unggahan yang berisi ulasan tentang sebuah destinasi wisata ataupun akomodasi yang menarik bisa memicu seseorang untuk melakukan perjalanan wisata.

Pencarian informasi mengenai tujuan wisata dapat dilakukan sengaja maupun tidak sengaja. Berdasarkan hasil dari responden, penggunaan google dan media sosial sangat efektif dalam pencarian infromasi destinasi dan akomodasi.

Setelah mendapatkan alternatif penginapan, responden mencari informasi lebih lanjut seperti foto-foto dan ulasan melalui media sosial seperti Instagram, youtube dan lain-lain. Media sosial bersifat viral, viral yang dimaksud adalah informasi dari suatu produk dapat berbagi (Puntoadi, 2011:5). Penggunaan media sosial menggunakan media sosial karena dapat melihat ulasan dari berbagai konsumen dan membandingkannya sebelum akhirnya memutuskan untuk menggunakannya. Ulasan dan komentar dari berbagai konsumen dalam sebuah sosial media juga digunakan sebagai 
pertimbangan sebelum menggunakan sebuah akomodasi.

Tahap terakhir dalam menentukan pemilihan hotel melalui media sosial adalah dengan menetapkan hotel yang akan dipilih berdasarkan informasi-informasi yang didapatkan. Hampir semua responden melakukan pemesanan penginapan disesuaikan dengan kebutuhan dan keinginan wisatawan terhadap aspek-aspek seperti kualitas akomodasi, harga, fasilitas, lokasi dan ulasan mengenai akomodasi tersebut.

Berikut adalah proses pemilihan hotel/akomodasi melalui media sosial :

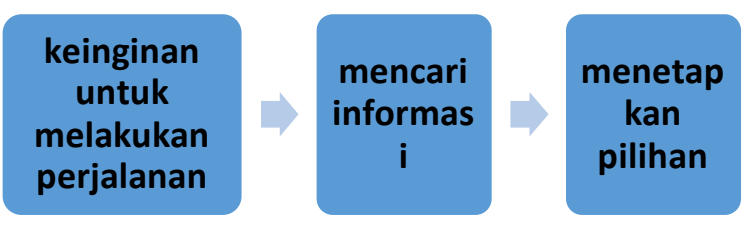

\section{Gambar 1 Proses Pemilihan Hotel Melalui Media Sosial}

Sumber : olahan penulis

\section{Simpulan}

Berdasarkan data dari 100 responden, sebanyak $75 \%$ memilih platform Traveloka sebagai sarana dalam membeli akomodasi melalui online. Hal tersebut dikarenakan kemudahan dalam mengakses platform tersebut dan banyaknya promo yang diberikan platform tersebut. Sedangkan $23 \%$ memilih Tiket.com dan sisanya $2 \%$ memilih platform online lainnya seperti Pegi-Pegi. Dari 100 responden, $80 \%$ responden menghabiskan 1 juta rupiah per malam untuk harga akomodasi yang mereka pilih.

Berdasarkan data dari responden, dengan mengunggah sebuah informasi/promosi lewat media sosial merupakan hal yang efektif dalam mendapat target pasar dengan profil responden tersebut. Selain itu dengan mengunggah foto yang menarik (instagramable) dapat menggugah konsumen untuk memilih akomodasi tersebut. Jika foto, video maupun informasi yang di tampilkan menarik dan kekinian, maka hal tersebut akan membuat mereka memilih akomodasi tersebut.

Berdasarkan data dari responden, tahapan dalam memilih hotel/akomodasi melalui media sosial berawal dari keinginan atau kebutuhan untuk berlibur sehingga membuat responden ingin melakukan pencarian mengenai tujuan dari perjalanan yang akan mereka lakukan. Keinginan untuk melakukan perjalanan juga dapat timbul ketika melihat unggahan yang menarik di media sosial. Unggahan yang berisi ulasan tentang sebuah destinasi wisata ataupun akomodasi yang menarik bisa memicu seseorang untuk melakukan perjalanan wisata.

\section{Daftar Pustaka}

Barrows, Clayton W., Powers, Tom and Reynolds, Dennis (2012). Introduction To The Hospitality Industry, 7th ed. USA: John Willey \& Sons, Inc., Hoboken, New Jersey.

Holloway, J. Christopher and Humphreys, Claire (2016). Business of Tourism, 10th ed. Pearson Education Limited, United Kingdom.

Johnson, R. Burke and Christensen, Larry (2017). Educational Research: Quantitative, Qualitative, and Mixed Approaches. 6th ed. SAGE Publications, Inc., California, USA.

Kementerian Perdagangan Republik Indonesia (2014). Panduan Optimalisasi Media Sosial Untuk Kementerian Perdagangan RI. Pusat Hubungan Masyarakat, Jakarta.

Kotler, Philip, Bowen and John T. and Makens, James C. (2014). Marketing for Hospitality and Tourism. 6th ed. Pearson Education, Inc., Prentice Hall, Upper Saddle River, New Jersey.

Kotler, Philip and Keller, Kevin L. (2016). A Framework for Marketing Management, 6th ed. Pearson Education Limited, Harlow, England.

Peraturan Pemerintah Pajak Daerah 2001, No.65 Deputi Sekretaris Kabinet (2001)

Puntoadi, Danis (2011). Menciptakan Penjualan Melalui Sosial Media. PT Elex Computindo, Jakarta, Indonesia.

Sekaran, Uma dan Bougie, Roger (2016). Research Methods for Business: A Skill Building Approach. 7th Ed. John Wiley \& Son Ltd.m United Kingdom.

Priyono.(2016).Metode Penelitian Kualititatif: Zifataman Publishing. 
Sugiono.(2016). Metode Penelitian Kuantitatif dan R\&D .Bandung : Alfabeta

Tarjo.(2019).Metode Penelitian Sistem 3x Baca. Yogyakarta: Deepublish Publisher. 